\title{
Displacement-based Design of Frames Consisting of Composite Beams and RC Columns
}

\author{
Wei Li*, Linzhu Sun and Kejia Yang \\ College of Civil Engineering and Architecture, Wenzhou University, Wenzhou 325035, P.R. China
}

\begin{abstract}
Performance-based seismic design (PBSD) method has been widely recognized in recent years, it can be used for the future structural design. And the direct displacement-based design method (DDBD) is one of the most effective ways to implement the performance-based seismic design (PBSD) theory in current. In this paper, aiming to the composite frame consisting of composite beams and continuous compound spiral hoop reinforced concrete columns (CCSHRCS), its DDBD flowchart is presented, and the structure identified performance objectives in the preliminary design process and specific seismic performance assessment methods are given. Finally, through the calculation results of CCSHRCS frame case that demonstrated the reasonableness of the method. It provides an effective tool for the seismic design of CCSHRCS frame structures
\end{abstract}

Keywords: Composite frame, seismic damage, direct displacement, performance level, storey drift ratio.

\section{INTRODUCTION}

Current codes (ASCE7-10 2010 [1]; GB50011-2010 [2]) specify the use of either the equivalent lateral-force method or the modal response spectrum method for the seismic design of frame structures. However, it has been demonstrated (Priestley 1993 [3]; Priestley et al. 2007 [4]) that force-based design methods possess a number of fundamental shortcomings such as the use of force-reduction (behavior) factors that are set without explicitly evaluation of ductility demands, and the use of elastic analysis to estimate inelastic force distributions in mixed structural systems (Priestley et al. 2007 [4]). To overcome such limitations with force-based design methods, a large number of displacement-based design methods have been proposed (Zonta et al. 2008 [5], Malekpour et al. 2011 [6], Sullivan et al. 2011 [7], Malekpour and Dashti 2013 [8], Sullivan 2013 [9]),

The most developed DBD methodology is the Direct DBD procedure which has been published as a text by Priestley et al. (2007 [4]) and in model-code format Sullivan et al. (2012 [10]). Existing guidelines for Direct DBD have been extensively developed and tested for RC structures (Sullivan et al. 2005 [11], 2006 [12], Malekpour and Dashti 2013[8]). However, few studies could be found about composite frames consisting of composite Beams and RC Columns. Recently, it has been shown (Sullivan 2013 [9]) that design base shears obtained for RC frame structures from DDBD can range from one half to four times of those obtained from the equivalent lateral force method currently specified in international codes. Given the general limitations of FBD methods, this paper proposes a Direct

*Address correspondence to this author at the Chashan University Town, Wenzhou City, Zhejiang Province, 325035, P.R. China, College of Civil Engineering and Architecture, Wenzhou University; Tel: +86-13506514071; E-mail: liweiwoaini521@hotmail.com
DBD procedure for composite CCSHRCS frames consisting of composite beams and continuous compound spiral hoop reinforced concrete columns and gauges its performance of the methodology through non-linear pushover analysis of a case study.

\section{DISPLACEMENT BASED SEISMIC DESIGN OF COMPOSITE FRAME STRUCTURE}

Fig. (1) illustrates the displacement based seismic design (DDBD) flowchart of the composite CCSHRCS frame, all of these will be discussed respectively in the next section except the dotted portion in the diagram.

\section{PERFORMANCE OBJECTIVE AND CRITERIA}

It can be divided into three groups according to the importance or destructive effects of the building. The unique performance objective has been determined to provide a communication platform between the owners and designers, enabling them to reach a consensus for structure performance under different levels of earthquake ( $\mathrm{Li}$ et al. 2012) [13]. Accordingly, the transparency of design goal is very critical. Based on references such as the latest specification or technical report of the U.S. (FEMA 356 2000, IBC 2003) [14, 15], Japan(JSCA 2000) [16], New Zealand and Australia (AS / NZS 1170) [17] and Canada (NBCC) [18], the latest edition of the seismic design code of buildings GB 50011-2010 [2] in China. The better approach is to adjust performance objectives for considering the earthquake level, especially in the case of high-level earthquake. It is the same as the general construction. In this case, there is no need to use the important coefficient. As shown in Fig. (2), three seismic hazard levels are considered and can be distinguished by return period, the great uncertainty of the earthquake are given, performance-based design requires an estimation of various seismic hazard levels, and the building performance has been divided into 


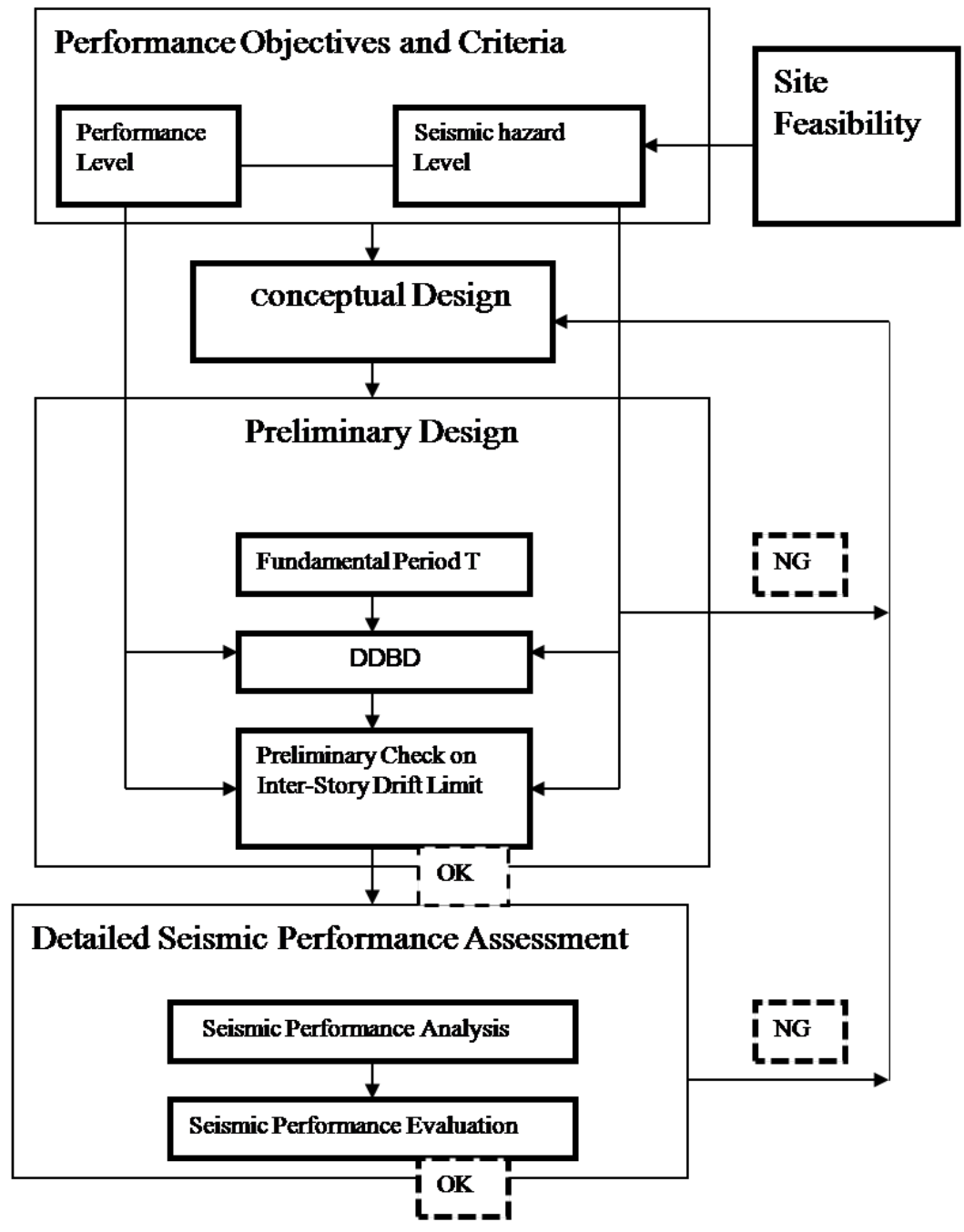

Fig. (1). Direct displacement-based seismic design flowcharts for new buildings.

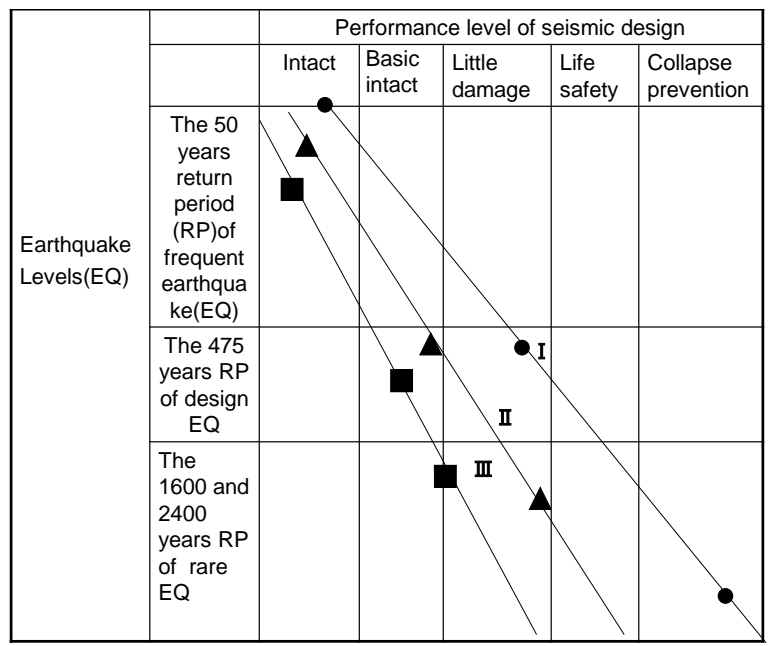

Fig. (2). Performance level and seismic hazard level.

five levels, intact, largely intact, minor damage, life safety and prevent collapse. For each building, the performance objective consists of three design goals, and each one is determined by considering the seismic hazard level and expected performance levels. For seismic resistance, group I , II, III can be used as performance goals.

All of the standard documents (SEAOC [19], FEMA450 [20], IBC2006 [21], seismic design code of buildings [2]) 
can provide a reference for the inter-storey drift ratio $\left(\theta_{T}\right)$ limitation of composite CCSHRCS frame as preliminary proposals.

A significant change in the proposed performance criteria exceed the current seismic design specification is whose demand of structural rigidity will increase, for very important buildings, such as group III. To achieve these performance objectives that requires the implementation of specific design criteria, that is component's index of capacity, distortion and detailed structure at each seismic standards. If only increasing the bearing capacity, it will enhance the safety. However, the deformation requirements will not be met. If improving the deformation capacity, the damage of the structure will almost be unchanged under minor earthquake, moderate earthquake, but it will improve the ability of resisting collapse. Therefore, the performance objectives usually focus on increasing the bearing capacity to postpone the structure into plastic stage and reducing plastic deformation, if necessary, while increasing the stiffness is needed to meet the deformation requirements, and the requirements of deformation capacity can be adjusted according to the degree that the structure and its elements entering elastic-plastic in moderate earthquake or large earthquake.

\section{SITE FEASIBILITY}

Site feasibility study is to ensure the performance objectives meet the requirements of site construction. It is similar with the current seismic design of buildings. When selecting construction sites, the relevant information of project and seismic activity as well as engineering geology and seismic geology should be considered. A favorable location should be selected for seismic fortification. Adverse lots should be avoided, if not being avoided, the effective measures should be taken. For dangerous location, buildings of class A and B must be prohibited to construct and class C buildings should not be built.

\section{CONCEPTUAL DESIGN}

Due to the complexity of the earthquake, as well as the complexity of structure, there are many non-deterministic of structural seismic design, and these non-deterministic are fully taken into account by following the design specifications. It is found from lessons learned in large earthquake disaster that concept design and calculation design own equal importance for structural seismic design.

Basic conceptual design emphasis on the redundancy and uniform continuity of strength, stiffness and ductility, respectively. Building height limits, horizontal and vertical irregularities, The seismic details of structural elements or structural connections without calculation, should meet the demand of seismic code or other specification.

\section{PRELIMINARY DESIGN}

The performance-based seismic design indicates that design process is determined by performance objectives. It can be completed by traditional bearing capacity based design methods and displacement based design methods, as the displacement-based seismic design method in the preliminary design stage can guide the design process of the entire structure by controlling the displacement. And there are many advantages in the design process, so this paper uses seismic design method based on displacement to design composite frame structure.

\subsection{Fundamental Period}

Through the comparative study on fundamental period proposed by FEMA 450 (FEMA, 2003) [20] and Seismic Design of Buildings (GB 50011-2010, 2010) [2], it was discovered that suggested values of FEMA 450 (FEMA, 2003) are more reasonable in most cases [20], so the empirical formula given by FEMA 450 is adopted for the fundamental period of structure system, its specific calculation can refer to the FEMA 450.

\subsection{Direct Displacement-based Seismic Design}

Direct displacement-based seismic design (DDBSD) is established by "alternative structure" method for reinforced concrete frame proposed by Gulkan and Sozen 1974 [22]. In this method, an equivalent elastic frame is used to substitute non-elastic frame, but it is different from the general elastic frame due to its considering the stiffness and damping characteristics. The alternative structure is elastic, so the modal analysis method and elastic response spectrum method can be used to calculate the load of structural design. Direct displacement-based seismic design (DDBSD) can make design structures reach the limit displacement. The basic steps of DDBSD method are shown in Fig. (3) (Priestley et al. 2007) [4].

\subsubsection{Step One: Select the Seismic Capacity}

For the seismic capacity of direct displacement-based seismic design, it is a displacement response spectrum generated from several elastic single freedom system under different damping, as shown in Fig. (3d), the response spectrum curve is the function of equivalent damping.

\subsubsection{Step Two: Select the Target Displacement}

Expected damage level can be selected according to the performance goals under determined seismic hazard level. Target displacement should be regarded as design displacement $\Delta_{d}$. According to the Fig. (3b), target displacement can be defined as the failure criterion based on the strain, curvature, rotation, or inter-storey drift ratio, $\theta_{T}$. Experimental studies have shown that inter-storey drift ratio can reflect the deformation consolidated results of each component interlayer and impact of storey height on reinforced concrete frame structure, and has a better correlation with the extent of structural damage. Therefore, the inter-storey drift ratio is selected to quantify performance levels.

For reinforced concrete frame structure, Priestley et al. 2007 [4] assumes that the lateral of the lower floors has reached the target displacement, hereby the displacement at each storey can be obtained, and the target displacement $\delta_{d, i}$ of storey $i$ is:

For $\mathrm{n} \leq 4$, 


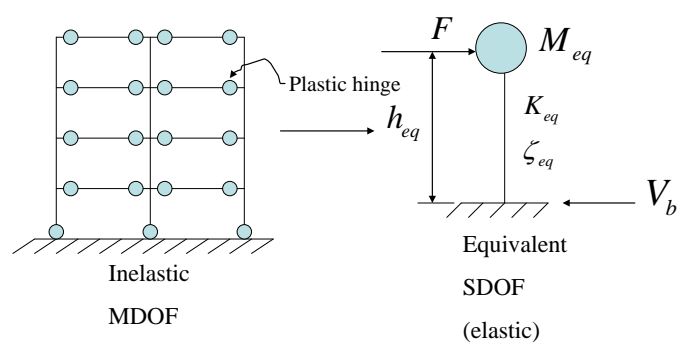

(a) SDOF simulation of Inelastic MDOF

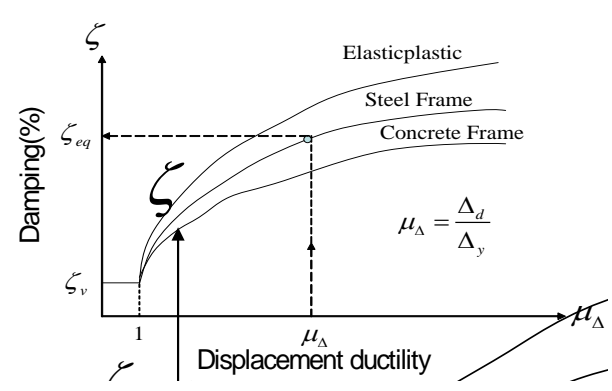

(c) Equivalent viscous damping vs. ductility

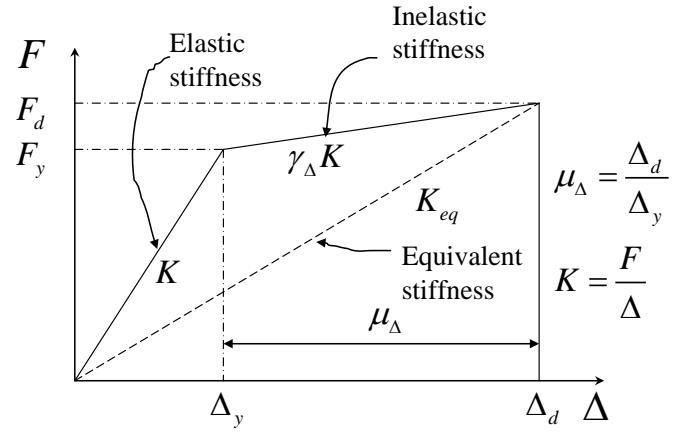

(b) Idealized Force-Displacement of Equivalent SDOF

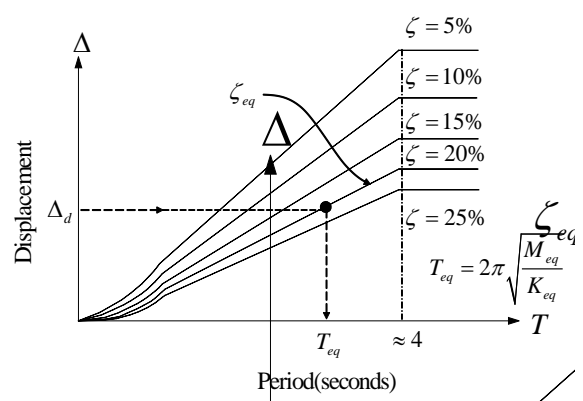

(d) Displacement response spectra

Fig. (3). Graphical illustration of DDBSD (modified from Priestley 2007) [4].

$\delta_{d, i}=\theta_{T} h_{f, i}$

For $4<\mathrm{n}<20$,

$\delta_{d, i}=\theta_{T} h_{f, i}\left(1-\frac{(n-4) h_{f, i}}{32 h_{f . n}}\right)$

For $\mathrm{n} \geq 20$,

$\delta_{d, i}=\theta_{T} h_{f, i}\left(1-\frac{h_{f, i}}{2 h_{f, n}}\right)$

Where, $\theta_{T}$ is target drift ratio; $n$ is the total storey number of frame structure; $h_{f, i}$ is the height from the ground to the $\mathrm{i}$ storey; $h_{f, n}$ is the height from the ground to the $\mathrm{n}$ storey.

The composite frame in the study is consisting of steel beams and continuous compound spiral hoop reinforced concrete column, so the lateral stiffness of the frame is mainly provided by the continuous compound spiral stirrups concrete columns. Based on this, this paper suggests calculating the target displacement $\delta_{d, i}$ in storey-i of composite CCSHRCS frame structure by using Eq. (1).

The designed response spectrum in the first step is generally produced by a single freedom system, so an important process for direct displacement-based seismic design is to convert multi-degree-of-freedom system structure into equivalent single freedom system, which includes, equivalent stiffness, equivalent mass, equivalent height and equivalent damping. As shown in Fig. (3a), design displacement curve $\left\{\delta_{\mathrm{d}}\right\}$ is applied in conversion process, which is a function of the target drift ratio. The select of displacement curve is consistent with the design level of inelastic fundamental mode under earthquake (Priestley et al. 2007) [4]. Characteristics of equivalent single freedom system are defined as follows:

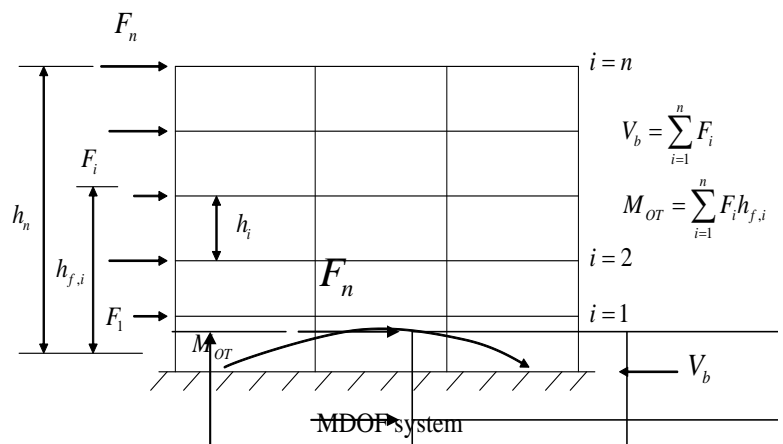

Fig. (4). Lateral force distribution.

$$
\begin{gathered}
\Delta_{d}=\frac{\sum_{i=1}^{n}\left(w_{i} \delta_{d, i}^{2}\right)}{\sum_{i=1}^{n}\left(w_{i} \delta_{d, i}\right)} \\
W_{e q}=\frac{\sum_{i=1}^{n}\left(w_{i} \delta_{d, i}\right)}{\Delta_{d}} \\
h_{e q}=\frac{\sum_{i=1}^{n}\left(w_{i} \delta_{d, i} h_{f, i}\right)}{\sum_{i=1}^{n}\left(w_{i} \delta_{d, i}\right)}
\end{gathered}
$$


Where, $w_{i}$ is the floor weight of storey-i; $\delta_{d, i}$ is the target displacement of storey-i; $n$ is the structural storey number.

\subsubsection{Step Three: Determination of the Yield Displacement}

The yield displacement $\Delta_{\mathrm{y}}$ is determined by the equivalent single freedom system based on the choice of design for different structural systems.

\subsubsection{Step Four: Calculation of Equivalent Mass}

The equivalent displacement of the storey displacement of storey-i in multi-degree-of-freedom system and equivalent single degree of freedom system, they are with a linear relationship:

$\delta_{i}=c_{i} \Delta_{e q}$

Where, $c_{i}$ is displacement adjustment coefficient of the dimensionless in storey-i.

Which is similar with Eq. (2), the equivalent displacement of equivalent single degree of freedom system is:

$$
\Delta_{e q}=\frac{\sum_{i=1}^{n}\left(m_{i} \delta_{i}^{2}\right)}{\sum_{i=1}^{n}\left(m_{i} \delta_{i}\right)}
$$

Where, $m_{i}$ is the floor mass of storey-i; $\delta_{i}$ is the floor displacement of storey-i in multi-degree of freedom system.

Due to the base shear $V_{b}$ and overturning moment $M_{O T}$ are established by using the equivalent single freedom system and the first modal multi-degree of freedom system, a linear relationship is assumed between acceleration and displacement of each floor during the conversion process, so there are:

$a_{i}=c_{i} a_{e q}$

Where, $a_{i}$ is the acceleration of storey-i; $a_{e q}$ is the equivalent acceleration of equivalent single degree of freedom system.

From Newton's second law that can be obtained:

$V_{b}=\sum_{i=1}^{n} F_{i}=\sum_{i=1}^{n} m_{i} a_{i}=a_{e q} \sum_{i=1}^{n} m_{i} c_{i}=M_{e q} a_{e q}$

So that is:

$$
M_{e q}=\sum_{i=1}^{n} m_{i} c_{i}
$$

Substituting Eq. (5) into Eq. (8) can obtain:

$$
M_{e q}=\frac{\sum_{i=1}^{n} m_{i} \delta_{i}}{\Delta_{e q}}
$$

\subsubsection{Step Five: The Calculation of Equivalent Damping}

Through the target displacement and yield displacement of the second and third step, displacement ductility capacity can be drawn from the equivalent single degree of freedom system,

$$
\mu_{\Delta}=\frac{\Delta_{d}}{\Delta_{y}}
$$

Eq. (11) is the approximation of multi-degree of freedom system ductility level, and the equivalent damping coefficient $\zeta_{e q}$ be defined as displacement ductility function under different materials and different systems. As shown in Fig. (3c), methods in FEMA 440 can be used.

\subsubsection{Step Six: Calculations of Equivalent Period and Design Base Shear}

The $T_{e q}$ equivalent single degree of freedom system can design the maximum response of response spectrum by entering the design level associated with target displacement, and the approximate response spectrum curve can be considered as equivalent period, as shown in Fig. (3d). Response spectrum curve is equivalent to damping functions. For single degree of freedom system, acceleration response spectra and displacement response spectrum can be expressed approximately as:

$S_{a}=\omega^{2} S_{d}=\left(\frac{2 \pi}{T}\right)^{2} S_{d}$

According to the acceleration response spectrum in seismic design of building [2], inserting into Eq. (12) that can be obtained:

$S_{a}=\alpha_{\max } g\left(0.45+\frac{\eta_{2}-0.45}{0.1} T\right)=\left(\frac{2 \pi}{T}\right)^{2} S_{d}=\frac{4 \pi^{2}}{T^{2}} S_{d}$

$\mathrm{T} \leq 0.1 \mathrm{~s}$

$S_{a}=\eta_{2} \alpha_{\max } g=\left(\frac{2 \pi}{T}\right)^{2} S_{d}=\frac{4 \pi^{2}}{T^{2}} S_{d}$

$0.1 \mathrm{~s} \leq \mathrm{T} \leq \mathrm{Tg}$

$S_{a}=\left(\frac{T_{g}}{T}\right)^{\gamma} \eta_{2} \alpha_{\max } g=\left(\frac{2 \pi}{T}\right)^{2} S_{d}=\frac{4 \pi^{2}}{T^{2}} S_{d}$

$\operatorname{Tg} \leq \mathrm{T} \leq 5 \operatorname{Tg} \quad(13 \mathrm{c})$

$S_{a}=\left[\eta_{2} 0.2^{\gamma}-\eta_{1}\left(T-5 T_{g}\right)\right] \alpha_{\max } g=\left(\frac{2 \pi}{T}\right)^{2} S_{d}=\frac{4 \pi^{2}}{T^{2}} S_{d}$

$5 \mathrm{Tg} \leq \mathrm{T} \leq 6.0 \mathrm{~s}$

To simplify Eq. (13) that can be obtained:

$T^{2}\left(0.45+\frac{\eta_{2}-0.45}{0.1} T\right)=\frac{4 \pi^{2}}{\alpha_{\max } g} S_{d} \quad \mathrm{~T} \leq 0.1 \mathrm{~s}$

$T^{2}=\frac{4 \pi^{2}}{\eta_{2} \alpha_{\max } g} S_{d} \quad 0.1 \mathrm{~s} \leq \mathrm{T} \leq \mathrm{T}_{\mathrm{g}}$

$T=\left(\frac{4 \pi^{2}}{T_{g}^{\gamma} \eta_{2} \alpha_{\max } g} S_{d}\right)^{\frac{1}{2-\gamma}} \mathrm{T}_{\mathrm{g}} \leq \mathrm{T} \leq 5 \mathrm{~T}_{\mathrm{g}}$ 


$$
T^{2}\left[\eta_{2} 0.2^{\gamma}-\eta_{1}\left(T-5 T_{g}\right)\right]=\frac{4 \pi^{2}}{\alpha_{\max } g} S_{d} \quad 5 \mathrm{~T}_{\mathrm{g}} \leq \mathrm{T} \leq 6.0 \mathrm{~s}
$$

Where, $\alpha_{\max }$ is the maximum value of seismic influence coefficient, for multi-intensity earthquake and rare intensity earthquake corresponding with basic intensity, which can value according to seismic design of buildings [2]. For the basic seismic intensity, when the fortification intensity is 7 degree, 8 degree and 9 degree, taking $0.23,0.45$ and 0.90 [23] respectively. $\gamma$ is a decaying exponential in decline segment of the curve; $\eta_{1}$ is down slope adjustment factor of beeline decreased segment; $\eta_{2}$ is damping adjustment factor; $\mathrm{T}_{\mathrm{g}}$ is characteristic period; $\mathrm{S}_{\mathrm{d}}$ is the displacement response spectrum, if it is single degree of freedom system, $S_{d}=\Delta_{e q}$.

Unless there are specific regulations, the damping ratio of building structures should be taken as 0.05, damping adjustment coefficient $\eta_{2}$ of seismic influence coefficient curves should use 1.0.

When the damping ratio of building structures is not equal to 0.05 according to relevant regulations, damping adjustment coefficient and shape parameters of the seismic influence coefficient curve should meet the following regulations:

$\gamma=0.9+\frac{0.05-\zeta}{0.3+6 \zeta}$

$\eta_{1}=0.02+\frac{0.05-\zeta}{4+32 \zeta}$

$\eta_{2}=1+\frac{0.05-\zeta}{0.08+1.6 \zeta}$

When $\eta_{1}$ calculated by Eq. (15b) is less than 0 , taking value 0 .When $\eta_{2}$ calculated according to Eq. (15c) is less than 0.55 , taking value 0.55 .

When calculating the equivalent period $T_{\text {eq }}$, approximation of basic period can be achieved according to FEMA 450. Then the equivalent period $T_{\text {eq }}$ can be calculated to determine according to Eq. (14) (15).

The equivalent stiffness $K_{e q}$ can be achieved from the classical structural dynamics theory of single degree of freedom system, equivalent stiffness is defined as the secant stiffness under the biggest reaction, as shown in Fig. (3b).
$K_{e q}=4 \pi^{2} \frac{M_{e q}}{T_{e q}^{2}}$

Base shear is the product of equivalent stiffness and target displacement:

$F=V_{b}=K_{e q} \Delta_{d}$

\subsubsection{Step Seven: Structural Analysis and Component Design}

Under the target displacement, the design base shear calculated by Eq. (17) can be assigned to the equivalent lateral force, and elastic analysis of the application structure modal is shown in Fig. (4).

$$
F_{i}=V_{b} \frac{w_{i} \delta_{d, i}}{\sum_{i=1}^{n}\left(w_{i} \delta_{d, i}\right)}
$$

To simplify this process, it is recommended to get the base lateral load-yield displacement curves by calculating the yield base shear for applying execute elastic analysis. Sullivan 2004 [24] suggested the response spectrum of initial stiffness or that of effective secant stiffness. The overall process of the improved direct displacement-based seismic design (DDBSD) is shown in Fig. (5).

In the case of DDBSD, the equivalent single degree of freedom system is converted to the effective elastic single degree of freedom system with yield point characteristics as the case definite in step C. Stiffness is calculated as follows:

$$
K_{e q}=K_{e f f, e q} \frac{\mu_{\Delta}}{\left(1+r_{\Delta}\left(\mu_{\Delta}-1\right)\right)}
$$

Where, $r_{\Delta}$ is posterior elastic stiffness ratio; $\mu_{\Delta}$ is displacement ductility ratio.

So the design shear is:

$$
F_{y}=K_{e q} \Delta_{y}=V_{b y}
$$

The distribution along the height of yield base shear is:

$$
F_{i}=V_{b y} \frac{w_{i} \delta_{d y, i}}{\sum_{i=1}^{n}\left(w_{i} \delta_{d y, i}\right)}
$$

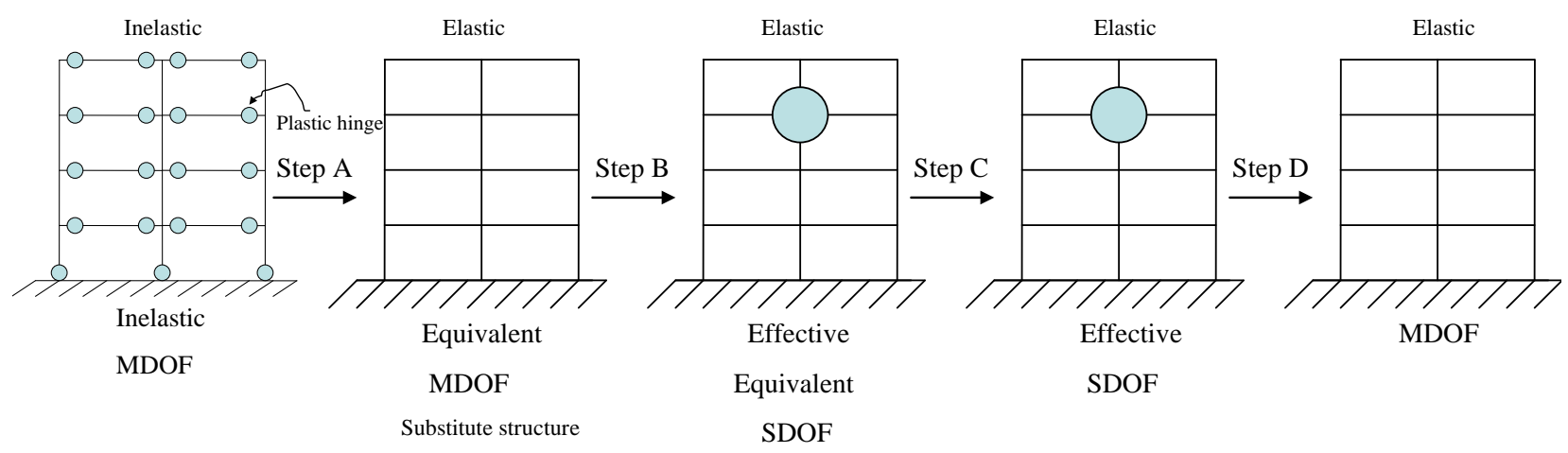

Fig. (5). Modified global sequence used in proposed DDBSD. 


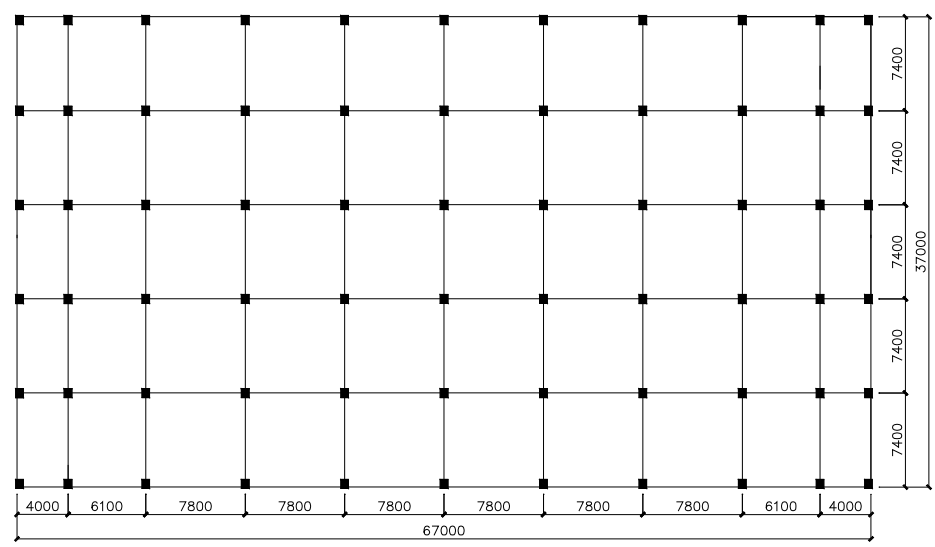

(a) Typical layout plan

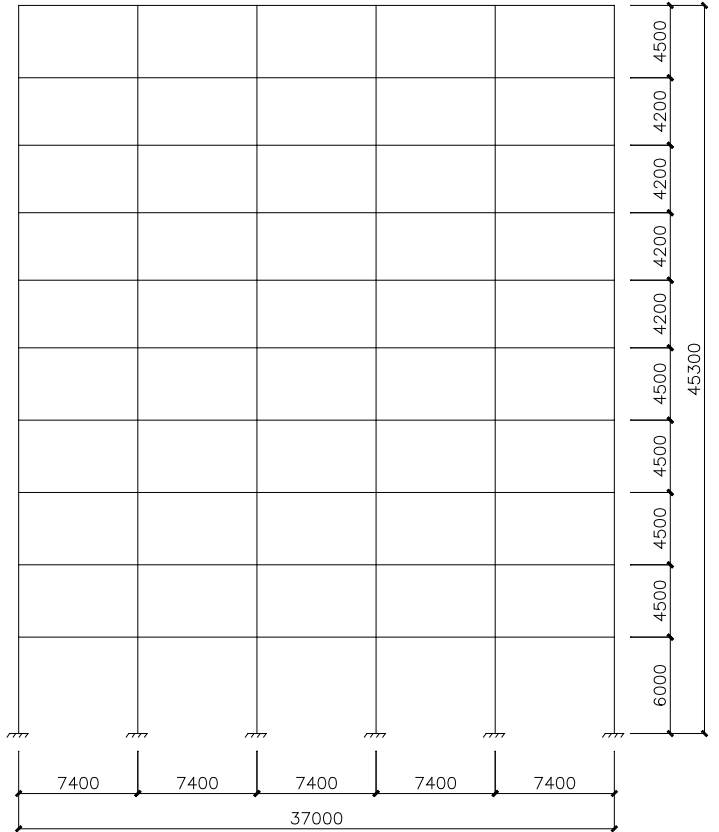

(b) North and south elevation drawing

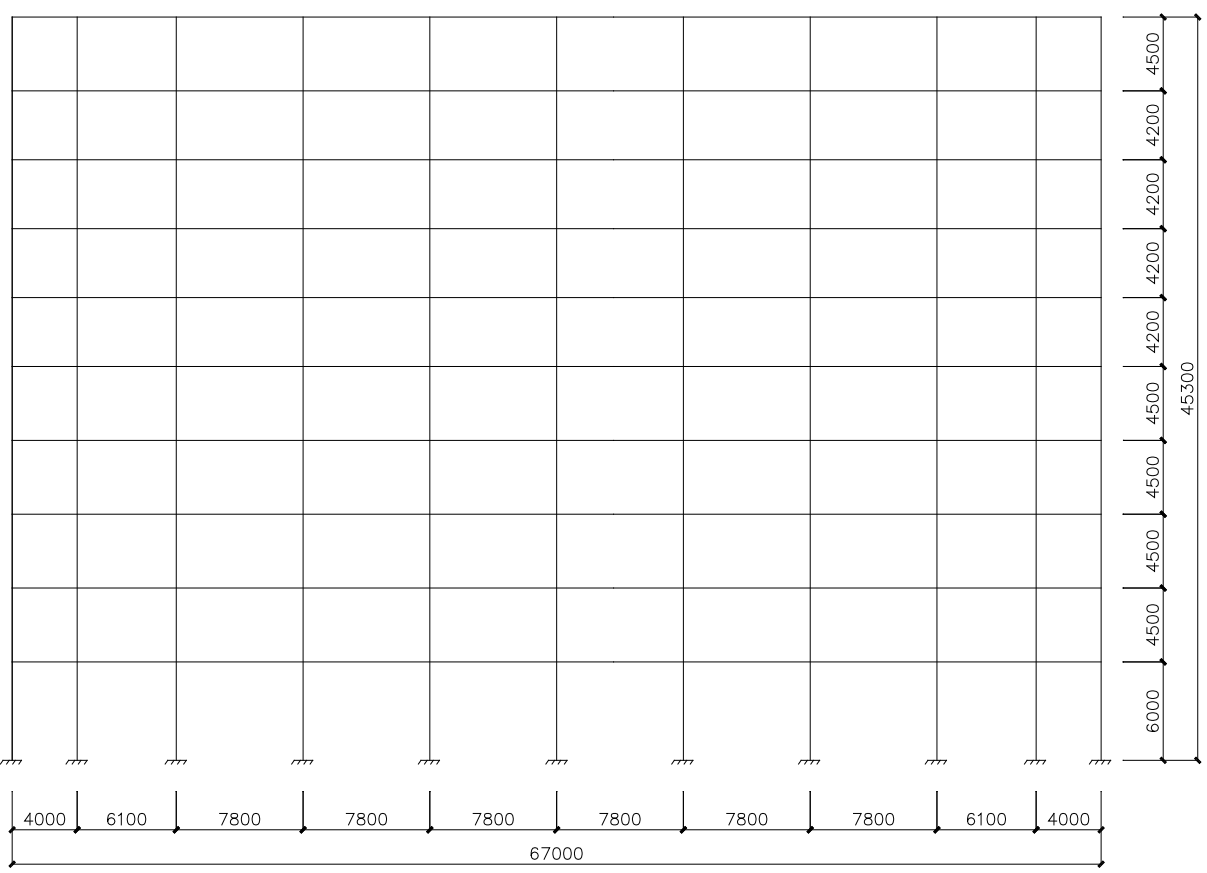

(c) East and west elevation drawing

Fig. (6). Floor framing typical plan and elevation.

Structural analysis and elastic strength and stiffness of elements that required can be directly determined through the yield point.

\subsection{Preliminary Checking the Limitation of Inter-storey Drift Ratio}

Regarding the complexity of inelastic analysis during the evaluating period of the specific seismic performance, the method preliminary checking by inter-storey drift ratio is simple and feasible, because inter-storey drift ratio in the early design stage can expose any defects related to stiffness. The maximum inter-storey drift ratio should meet the requirements.

\section{SPECIFIC SEISMIC PERFORMANCE EVALUATION}

Due to considering the size of standards and the construction convenience in the structural design, the 
structure may not reach the seismic ductility assumed. Moreover, considering that using nonlinear analysis are not clear enough during the preliminary design phase. The real over-strength factor may be different from the preliminary design phase. Therefore, it is necessary to adopt specific seismic performance evaluation, although cannot guarantee reliable100\%, it can guarantee structural seismic performance to meet the expected seismic criterias and objectives

\subsection{Seismic Performance Analysis}

In this study, the minimum allowable analysis method is used for the performance evaluation and the specific contents may refer to literature [13]. The select of this method is based on seismic risk level, and the method is used for the preliminary design based on building height and the system irregularities.

This Method is used to evaluate the structural seismic performance at all levels of earthquake design. When using non-linear time-historey analysis, nonlinear dynamic or gradually dynamic analysis can be applied to evaluate the ductility performance of Structural system. Considering the complexity of nonlinear dynamic analysis, nonlinear static analysis is adopted.

\subsection{Evaluation of Seismic Performance}

Structural performance point corresponding to seismic hazard level that can be calculated by seismic coefficient method or capacity spectrum method (Li et al. 2012) [13], what can also be calculated by direct displacement-based design method. The target displacement of structural pushover to performance points, the performance points is close to performance of structural components that the earthquake hazard level occurs. The seismic performance evaluation of the composite frame (CCSHRCS) is similar with performance criteria. Due to performance criteria considering all performance objectives. In addition to special considering about the characteristics of individual components.

\subsubsection{Structural System}

- Considering the vertical bearing capacity of the structure, it will not collapse when any one component of the structure was removed.

- Considering the structure lateral stiffness, destruction or weak layer mechanism of structure can be clearly understood through distribution of plastic hinge and plastic deformation process. In nonlinear pushover analysis, degradation of strength can be controlled by the definition of damage states.

- Considering the lateral deformation capacity of structure, the maximum inter-storey drift ratio and inelastic displacement ductility coefficient can be figured out to compare with acceptable performance criteria. The very weak layer and very torsion irregular shape must be avoided, that is the stiffness of each floor should be not less than $60 \%$ of the stiffness above, or not less than $70 \%$ of the average stiffness of total floor. The maximum horizontal displacement under seismic action shall not exceed 1.4 times of the average displacement of two horizontal directions.

- The distance between adjacent buildings should not be less than the most storey drift under the fortification earthquake or $70 \%$ of the maximum inter-storey drift under rare earthquake, in order to avoid mutual squeezing between the building structures.

\subsubsection{Structural Members}

- The structural members need to remain elastic according to the damaged mechanism and the elastic behavior examination of members should be carried out.

- Deformability examination of structure controlled by deformation, based on performance criteria, not less

Table 1. Storey shear under performance level 1.

\begin{tabular}{|c|c|c|c|c|c|c|c|}
\hline Storey level & $\begin{array}{c}\text { Height } \\
h_{f, i} / \mathbf{m}\end{array}$ & $\begin{array}{c}\text { Lateral drift } \\
\delta_{d, i} / \mathbf{m m}\end{array}$ & Mass $m_{i} t$ & $\begin{array}{c}\text { Lateral force } \\
\quad F_{i} / \mathbf{k N}\end{array}$ & $\begin{array}{c}\text { Storey force } \\
V_{i} / \mathbf{k N}\end{array}$ & $\begin{array}{l}\text { Storey drift } \delta_{d, i} \\
-\delta_{d, i-1} / \mathbf{m m}\end{array}$ & Storey drift ratio $\theta_{\mathrm{T}}$ \\
\hline 10 & 45.3 & 73.6125 & 874.8325 & 83.64113 & 83.64113 & 5.79263 & 0.001287 \\
\hline 9 & 40.8 & 67.81987 & 3501.3950 & 308.4193 & 392.0604 & 5.70894 & 0.001359 \\
\hline 8 & 36.6 & 62.11093 & 3130.8794 & 252.5677 & 644.6281 & 6.001 & 0.001429 \\
\hline 7 & 32.4 & 56.10993 & 3130.8794 & 228.1652 & 872.7933 & 6.29304 & 0.001498 \\
\hline 6 & 28.2 & 49.81689 & 3188.2141 & 206.2849 & 1079.078 & 6.5851 & 0.001568 \\
\hline 5 & 24 & 43.23179 & 3200.5891 & 179.7118 & 1258.79 & 7.37955 & 0.00164 \\
\hline 4 & 19.5 & 35.85224 & 3200.5891 & 149.0355 & 1407.825 & 7.71482 & 0.001714 \\
\hline 3 & 15 & 28.13742 & 3215.4390 & 117.5081 & 1525.334 & 8.05009 & 0.001789 \\
\hline 2 & 10.5 & 20.08733 & 3300.0281 & 86.09606 & 1611.43 & 8.38534 & 0.001863 \\
\hline 1 & 6 & 11.70199 & 4469.4189 & 67.92884 & 1679.358 & 11.70199 & 0.00195 \\
\hline$\sum$ & & & & 1679.358 & & & \\
\hline
\end{tabular}


than $80 \%$ of the members need to meet the allowable ductility displacement coefficient of structure system.

- Strength test of the structure that controlled by bearing capacity, it should ensure the minimum strength of structural materials not less than the total loads being.

In this paper, the check of component performance is not used under performance goals preventing the collapse, but the stability of the structural system must be guaranteed.

\section{ANALYSIS OF EXAMPLES}

In this paper, seismic design for composite frame (CCSHRCS) is carried out by using direct displacementbased seismic design method, as shown in Fig. (6), and the detailed design process will be explained below, except the site feasibility. It is assumed that there is no liquefaction of the site foundation.

\subsection{Performance Objective and Criterion}

The structural performance objectives consist of three
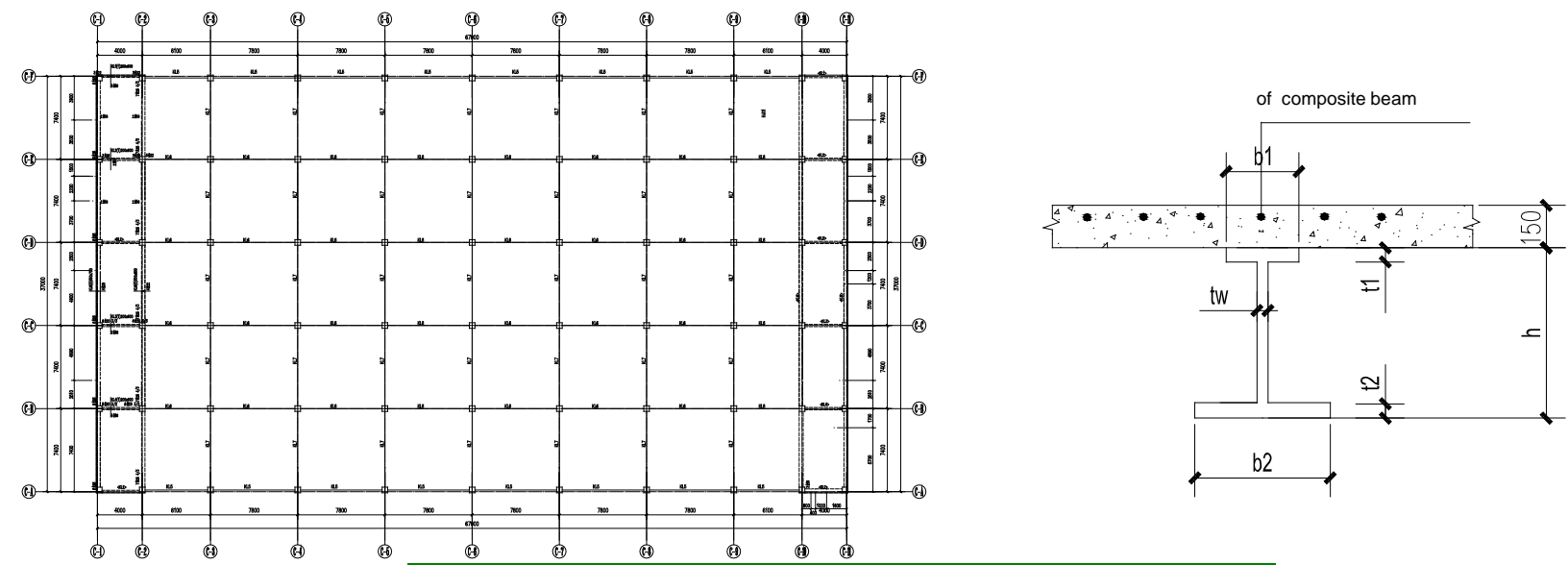

The sizes of column section design objectives, each one is determined by considering the seismic hazard level and expected performance level. Group I , II , III are used as seismic performance objectives. Under low levels of seismic action and when theoretical recurrence stage is 50 years, group I should be used as performance objectives, as shown in Fig. (2). When building is "intact" and "basically intact", the structure remains in elastic state and meets the requirement that the limit of inter-storey drift ratio is 0.002 to 0.0022 under frequent earthquakes. Under the action of moderate level earthquakes when theoretical recurrence stage is 475 years, it is shown in Fig. (2). Structural elements appears slight plastic deformation, but does not reach the yield state, and meets the requirement that the limit of inter-storey drift ratio is 0.005 ; when significant plastic deformation appears on structural members, it meets the requirement that the limit of inter-storey drift ratio is 0.015. Under high level seismic action, when theoretical recurrence stage is 1600 to 2400 years, it is shown in Fig. (2). Structure meets the requirement of "prevent collapse", limit of its inter-storey drift ratio is 0.025 .

According to seismic design code of buildings GB

\begin{tabular}{|c|c|}
\hline \multicolumn{2}{|c|}{ The sizes of column section } \\
\hline Storey level & $\begin{array}{l}\text { Section size } \\
\quad \mathrm{b} \times \mathrm{h}\end{array}$ \\
\hline $7 \sim 10$ & $400 \times 400$ \\
\hline $3 \sim 6$ & $500 \times 500$ \\
\hline $1 \sim 2$ & $600 \times 600$ \\
\hline \multicolumn{2}{|l|}{ The sizes of beam section } \\
\hline The number of members & $\begin{array}{c}\text { Section size } \\
\mathrm{h} \times \mathrm{b}_{1} \times \mathrm{t}_{1} \times \mathrm{t}_{2} \times \mathrm{t}_{\mathrm{w}}(\mathrm{mm})\end{array}$ \\
\hline KL7 & $\begin{array}{c}\mathrm{H} 460 \times 120 \times 4 \times 100 \times 10 \times 11 \\
\mathrm{H} 460 \times 120 \times 4 \times 100 \times 10 \times 6\end{array}$ \\
\hline KL6 & $\begin{array}{c}\mathrm{H} 430 \times 120 \times 4 \times 100 \times 12 \times 10 \\
\mathrm{H} 430 \times 120 \times 4 \times 100 \times 12 \times 6\end{array}$ \\
\hline KL5 & $\mathrm{H} 390 \times 120 \times 4 \times 100 \times 10 \times 8$ \\
\hline & H390 $\times 120 \times 4 \times 100 \times 10 \times 6$ \\
\hline
\end{tabular}

Fig. (7). Plan sizes of beam-colulm. 
Table 2. Storey shear under performance level 2.

\begin{tabular}{|c|c|c|c|c|c|c|c|}
\hline Storey level & $\begin{array}{c}\text { Height } \\
\boldsymbol{h}_{f, i} / \mathbf{m}\end{array}$ & $\begin{array}{c}\text { Lateral drift } \\
\delta_{d, i} / \mathbf{m m}\end{array}$ & Mass $m_{i / t}$ & $\begin{array}{c}\text { Lateral force } \\
F_{i} / \mathbf{k N}\end{array}$ & $\begin{array}{c}\text { Storey force } \\
V_{i} / \mathbf{k N}\end{array}$ & $\begin{array}{l}\text { Storey drift } \delta_{d, i} \\
-\delta_{d, i-1} / \mathbf{m m}\end{array}$ & Storey drift ratio $\theta_{\mathrm{T}}$ \\
\hline 10 & 45.3 & 80.97375 & 874.8325 & 77.36652 & 77.36652 & 6.3719 & 0.001416 \\
\hline 9 & 40.8 & 74.60185 & 3501.3950 & 285.2822 & 362.6487 & 6.27983 & 0.001495 \\
\hline 8 & 36.6 & 68.32202 & 3130.8794 & 233.6205 & 596.2692 & 6.60109 & 0.001572 \\
\hline 7 & 32.4 & 61.72093 & 3130.8794 & 211.0487 & 807.3179 & 6.92235 & 0.001648 \\
\hline 6 & 28.2 & 54.79858 & 3188.2141 & 190.8098 & 998.1277 & 7.24361 & 0.001725 \\
\hline 5 & 24 & 47.55497 & 3200.5891 & 166.2301 & 1164.358 & 8.11751 & 0.001804 \\
\hline 4 & 19.5 & 39.43746 & 3200.5891 & 137.8551 & 1302.213 & 8.4863 & 0.001886 \\
\hline 3 & 15 & 30.95116 & 3215.4390 & 108.6929 & 1410.906 & 8.85509 & 0.001968 \\
\hline 2 & 10.5 & 22.09607 & 3300.0281 & 79.63731 & 1490.543 & 9.22388 & 0.00205 \\
\hline 1 & 6 & 12.87219 & 4469.4189 & 62.83294 & 1553.376 & 12.87219 & 0.002145 \\
\hline$\sum$ & & & & 1553.376 & & & \\
\hline
\end{tabular}

Table 3. Storey shear under performance level 3.

\begin{tabular}{|c|c|c|c|c|c|c|c|}
\hline Storey level & $\begin{array}{c}\text { Height } \\
h_{f, i} / \mathbf{m}\end{array}$ & $\begin{array}{c}\text { Lateral drift } \\
\delta_{d, i} / \mathbf{m m}\end{array}$ & Mass $m_{i} t$ & $\begin{array}{c}\text { Lateral force } \\
\quad F_{i} / \mathbf{k N}\end{array}$ & $\begin{array}{c}\text { Storey force } \\
\qquad V_{i} / \mathbf{k N} \\
\end{array}$ & $\begin{array}{l}\text { Storey drift } \delta_{d, i} \\
-\delta_{d, i-1} / \mathbf{m m}\end{array}$ & Storey drift ratio $\theta_{\mathrm{T}}$ \\
\hline 10 & 45.3 & 184.0313 & 874.8325 & 269.5998 & 269.5998 & 14.4816 & 0.003218 \\
\hline 9 & 40.8 & 169.5497 & 3501.3950 & 994.1253 & 1263.725 & 14.2724 & 0.003398 \\
\hline 8 & 36.6 & 155.2773 & 3130.8794 & 814.0992 & 2077.824 & 15.0025 & 0.003572 \\
\hline 7 & 32.4 & 140.2748 & 3130.8794 & 735.443 & 2813.267 & 15.7326 & 0.003746 \\
\hline 6 & 28.2 & 124.5422 & 3188.2141 & 664.9163 & 3478.184 & 16.4627 & 0.00392 \\
\hline 5 & 24 & 108.0795 & 3200.5891 & 579.2636 & 4057.447 & 18.44891 & 0.0041 \\
\hline 4 & 19.5 & 89.63059 & 3200.5891 & 480.3847 & 4537.832 & 19.28705 & 0.004286 \\
\hline 3 & 15 & 70.34354 & 3215.4390 & 378.7629 & 4916.595 & 20.1252 & 0.004472 \\
\hline 2 & 10.5 & 50.21834 & 3300.0281 & 277.5128 & 5194.108 & 20.96337 & 0.004659 \\
\hline 1 & 6 & 29.25497 & 4469.4189 & 218.9544 & 5413.062 & 29.25497 & 0.004876 \\
\hline$\sum$ & & & & 5413.062 & & & \\
\hline
\end{tabular}

50011-2010 [2], under the action of low level earthquake, moderate level and high-level earthquake, damping ratio of elastic and inelastic design response spectra are both used $5 \%$.

\subsection{Conceptual Design}

Plane and elevation layout of building structure are shown in Fig. (6), and the span of building structure plane in the $X$ direction are all $7.8 \mathrm{~m}$, except the two ends are $4 \mathrm{~m}$ and $6.1 \mathrm{~m}$. The span of building structure plane in the $\mathrm{Y}$ direction is $7.4 \mathrm{~m}$. The storey height layout of building structure is uniform, the storey height of the first floor is $6 \mathrm{~m}$, the storey height from the second floor to the fifth floor is $4.5 \mathrm{~m}$, the storey height from the sixth to the ninth floor is $4.2 \mathrm{~m}$, the storey height of the top floor is $4.5 \mathrm{~m}$, the total height of the structure is $45.3 \mathrm{~m}$, it meets the regularity and height limited requirements in seismic design code of buildings GB 500112010 [2]. Seismic fortification intensity is 7-degree, with II class site, design earthquake grouped into the first group, the characteristic period $T_{g}=0.35 \mathrm{~s}$. Representative values of gravity load are: floor- $1, \mathrm{~m}_{1}=4469.4189 \mathrm{t}$; floor- $2, \mathrm{~m}_{2}=$ 3300.0281t; floor-3, $\mathrm{m}_{3}=3215.4390 t$; floor $4 \sim 5, \mathrm{~m}_{4-5}=$ 3200.5891t; foor $-6, \mathrm{~m}_{6}=3188.2141 \mathrm{t}$; floor $7 \sim 8, \mathrm{~m}_{7-8}=$ 3130.8794t; floor-9, $\mathrm{m}_{9}=3501.3950 \mathrm{t}$; floor-10, $\mathrm{m}_{10}=$ 874.8325t, strength grade of all concrete columns C55, strength grade of concrete slab C30, using steel girder of grade Q345.

\subsection{Preliminary Design}

According to the empirical formula provided according to FEMA 450, the fundamental period of structure system is $2.76 \mathrm{~s}$. 
Table 4. Storey shear under performance level 4.

\begin{tabular}{|c|c|c|c|c|c|c|c|}
\hline Storey level & $\begin{array}{l}\text { Height } \\
h_{f, i} / \mathbf{m}\end{array}$ & $\begin{array}{c}\text { Lateral drift } \\
\delta_{d, i} / \mathbf{m m}\end{array}$ & Mass $m_{i} t$ & $\begin{array}{c}\text { Lateral force } \\
\quad F_{i} / \mathbf{k N}\end{array}$ & $\begin{array}{c}\text { Storey force } \\
V_{i} / \mathbf{k N}\end{array}$ & $\begin{array}{l}\text { Storey drift } \delta_{d, i} \\
-\delta_{d, i-1} / \mathbf{m m}\end{array}$ & Storey drift ratio $\theta_{\mathrm{T}}$ \\
\hline 10 & 45.3 & 552.0938 & 874.8325 & 109.7356 & 109.7356 & 43.4448 & 0.009654 \\
\hline 9 & 40.8 & 508.649 & 3501.3950 & 404.6403 & 514.3759 & 42.817 & 0.010195 \\
\hline 8 & 36.6 & 465.832 & 3130.8794 & 331.3641 & 845.74 & 45.0075 & 0.010716 \\
\hline 7 & 32.4 & 420.8245 & 3130.8794 & 299.3486 & 1145.089 & 47.1978 & 0.011238 \\
\hline 6 & 28.2 & 373.6267 & 3188.2141 & 270.642 & 1415.731 & 49.3883 & 0.011759 \\
\hline 5 & 24 & 324.2384 & 3200.5891 & 235.7785 & 1651.509 & 55.3466 & 0.012299 \\
\hline 4 & 19.5 & 268.8918 & 3200.5891 & 195.5317 & 1847.041 & 57.8612 & 0.012858 \\
\hline 3 & 15 & 211.0306 & 3215.4390 & 154.1685 & 2001.209 & 60.3756 & 0.013417 \\
\hline 2 & 10.5 & 150.655 & 3300.0281 & 112.9564 & 2114.166 & 62.8901 & 0.013976 \\
\hline 1 & 6 & 87.7649 & 4469.4189 & 89.12134 & 2203.287 & 87.7649 & 0.014627 \\
\hline$\Sigma$ & & & & 7145.228 & & & \\
\hline
\end{tabular}

Table 5. Storey shear under performance level 5.

\begin{tabular}{|c|c|c|c|c|c|c|c|}
\hline Storey level & $\begin{array}{l}\text { Height } \\
h_{f, i} / \mathbf{m}\end{array}$ & $\begin{array}{c}\text { Lateral drift } \\
\delta_{d, i} / \mathbf{m m}\end{array}$ & Mass $m_{i} \mathbf{t}$ & $\begin{array}{c}\text { Lateral force } \\
\qquad F_{i} / \mathbf{k N}\end{array}$ & $\begin{array}{l}\text { Storey force } \\
\quad V_{i} / \mathbf{k N}\end{array}$ & $\begin{array}{c}\text { Storey drift } \\
\delta_{d, i}-\delta_{d, i-1} / \mathbf{m m}\end{array}$ & Storey drift ratio $\theta_{\mathrm{T}}$ \\
\hline 10 & 45.3 & 920.1563 & 874.8325 & 368.8913 & 368.8913 & 72.408 & 0.016091 \\
\hline 9 & 40.8 & 847.7483 & 3501.3950 & 1360.254 & 1729.145 & 71.3617 & 0.016991 \\
\hline 8 & 36.6 & 776.3866 & 3130.8794 & 1113.926 & 2843.071 & 75.0124 & 0.01786 \\
\hline 7 & 32.4 & 701.3742 & 3130.8794 & 1006.301 & 3849.372 & 78.6631 & 0.018729 \\
\hline 6 & 28.2 & 622.7111 & 3188.2141 & 909.8002 & 4759.173 & 82.3137 & 0.019599 \\
\hline 5 & 24 & 540.3974 & 3200.5891 & 792.6019 & 5551.774 & 92.2445 & 0.020499 \\
\hline 4 & 19.5 & 448.1529 & 3200.5891 & 657.3067 & 6209.081 & 96.4352 & 0.02143 \\
\hline 3 & 15 & 351.7177 & 3215.4390 & 518.2585 & 6727.34 & 100.626 & 0.022361 \\
\hline 2 & 10.5 & 251.0917 & 3300.0281 & 379.7186 & 7107.058 & 104.8169 & 0.023293 \\
\hline 1 & 6 & 146.2748 & 4469.4189 & 299.5936 & 7406.652 & 146.2748 & 0.024379 \\
\hline$\sum$ & & & & 7406.652 & & & \\
\hline
\end{tabular}

According to engineering experience, the sizes of composite(CCSHRCS) frame structure are selected initially, as shown in Fig. (7).

The displacement based seismic design method can be used to check inter-storey drift ratio of composite frame structure (CCSHRCS). The calculation results have shown that all the floors meet the requirements of allowed interstorey drift ratio under performance objectives. It indicates that the selection of structural section dimensions is reasonable in the preliminary design.

\subsection{Specific Evaluation of Seismic Performance}

Elastic static analysis can be used for frequent earthquake, and nonlinear static pushover analysis can be used for moderate earthquake and rare earthquake.

\subsubsection{To Design According to the Performance Level of "Intact"}

The structural performance level in the elastic state with small earthquakes of 7-degree, taking limit value of interstorey displacement ratio, $\theta_{T \mathrm{a}}=0.002$, figuring out lateral $\delta_{d, i}$ by Eq. (1), substituting into Eq. (6) to obtain the structure equivalent displacement $\Delta_{\mathrm{eq}}=50.48549 \mathrm{~mm}$, substituting equivalent displacement into Eq. (7) to obtain the equivalent mass $M_{e q}=25611.4$ t. By Eq. (14) (15) the equivalent period $T_{e q}=5.513257 \mathrm{~s}$ can be determined, substituting the equivalent mass and equivalent period into (16) equivalent stiffness $K_{e q}$ $=33.26417 \mathrm{kN} / \mathrm{mm}$ can be determined, and finally calculate the total shear $V_{b}$ of structure base and lateral force $F_{i}$ of 
Table 6. Distribution of base shear by pushover analysis.

\begin{tabular}{|c|c|c|c|c|c|c|c|c|}
\hline $\begin{array}{c}\text { Storey } \\
\text { level }\end{array}$ & $\begin{array}{c}\text { Height } \\
h_{f, i} / \mathbf{m}\end{array}$ & Mass $m_{i / t}$ & $\begin{array}{c}\text { Lateral force under } \\
\text { parabolic distribution } \\
F_{i} / \mathbf{k N}\end{array}$ & $\begin{array}{c}\text { Storey } \\
\text { force } V_{i} / \mathbf{k N}\end{array}$ & $\begin{array}{c}\text { Lateral } \\
\text { drift } \\
\delta_{d, i} / \mathbf{m m}\end{array}$ & $\begin{array}{c}\text { Lateral force under } \\
\text { triangle distribution } \\
\qquad F_{i} / \mathbf{k N} \\
\end{array}$ & $\begin{array}{c}\text { Storey } \\
\text { force } V_{i} / \mathbf{k N}\end{array}$ & $\begin{array}{c}\text { Lateral } \\
\text { drift } \\
\delta_{d, i} / \mathbf{m m}\end{array}$ \\
\hline 10 & 45.3 & 79.530227 & 588.7597 & 588.7597 & 317.3523 & 473.6308 & 473.6308 & 255.2957 \\
\hline 9 & 40.8 & 318.30864 & 2020.327 & 2609.087 & 1088.994 & 1707.332 & 2180.963 & 920.2836 \\
\hline 8 & 36.6 & 284.6254 & 1539.762 & 4148.85 & 829.9604 & 1369.507 & 3550.47 & 738.1895 \\
\hline 7 & 32.4 & 284.6254 & 1287.042 & 5435.892 & 693.7394 & 1212.35 & 4762.82 & 653.4792 \\
\hline 6 & 28.2 & 289.83765 & 1068.532 & 6504.424 & 575.9587 & 1074.517 & 5837.337 & 579.1846 \\
\hline 5 & 24 & 290.96265 & 846.1649 & 7350.589 & 456.0985 & 918.0323 & 6755.37 & 494.8364 \\
\hline 4 & 19.5 & 290.96265 & 623.4747 & 7974.064 & 336.0644 & 745.9012 & 7501.271 & 402.0545 \\
\hline 3 & 15 & 292.31264 & 425.8295 & 8399.893 & 229.5299 & 576.4323 & 8077.703 & 310.7077 \\
\hline 2 & 10.5 & 300.00255 & 258.6281 & 8658.521 & 139.4053 & 414.1176 & 8491.821 & 223.2171 \\
\hline 1 & 6 & 406.31081 & 153.7931 & 8812.314 & 82.89732 & 320.4934 & 8812.314 & 172.7519 \\
\hline$\sum$ & & & & 8812.314 & & 8812.314 & & \\
\hline
\end{tabular}

each floor by Eq. (17) and (18), and the results are shown in Table 1.

Using the same calculation method can obtain design under performance level

\subsubsection{To Design According to the Performance Level of " Basically Intact "}

The structural performance level with small earthquakes of 7-degree, taking limited value of inter-storey drift ratio $\theta_{T a}$ $=0.002$, figuring out lateral $\delta_{\mathrm{d}}$ by formula (1), i, substituting into Eq. (6) to obtain the structure of equivalent displacement $\Delta_{\mathrm{eq}}=50.53404 \mathrm{~mm}$, substituting equivalent displacement into Eq. (7) to obtain the equivalent mass $\mathrm{M}_{\mathrm{eq}}$ $=25611.4$ t. By Eq. (14) $\sim(15)$ the equivalent period $\mathrm{T}_{\mathrm{eq}}=$ $6.012262 \mathrm{~s}$ can be determined, substituting the equivalent mass and equivalent period into Eq. (16), equivalent stiffness $K_{e q}=27.9716 \mathrm{kN} / \mathrm{mm}$ can be determined, and finally calculates the total shear $V_{b}$ of structure base and lateral force $F_{i}$ of each floor by formula (17) and (18), and the results are shown in Table 2.

\subsubsection{To Design According to the Performance Level of "Slight Damage"}

The structural performance level with moderate earthquake of 7-degree, taking limit value of inter-storey drift ratio $\theta_{T \mathrm{a}}=0.005$, figuring out lateral $\delta_{d, i}$ by Eq. (1), substituting into Eq. (6) to obtain the structure equivalent displacement $\Delta_{\mathrm{eq}}=126.2137 \mathrm{~mm}$, substituting equivalent displacement into Eq. (7) to obtain the equivalent mass $M_{e q}=$ 25611.4t. By Eq. (14) - (15) the equivalent period $T_{e q}=$ $4.855437 \mathrm{~s}$ can be determined, substituting the equivalent mass and equivalent period into Eq. (16), equivalent stiffness $K_{e q}=42.88806 \mathrm{kN} / \mathrm{mm}$ can be determined, and finally calculates the total shear $V_{b}$ of structure base and lateral force Fi of each floor by Eq. (17) and (18), and the results are shown in Table 3.

\subsubsection{To Design According to the Performance Level of " Life Safety"}

The structural performance level with moderate earthquake of 7-degree, taking limit value of inter-storey drift ratio $\theta_{T \mathrm{a}}=0.015$, figuring out lateral $\delta_{d, i}$ by formula (1), substituting into Eq. (6) to obtain the structure equivalent displacement $\Delta_{\mathrm{eq}}=378.6412 \mathrm{~mm}$, substituting equivalent displacement into Eq. (7) to obtain the equivalent mass $M_{e q}=$ 25611.4t. By Eq. (14) - (15) the equivalent period $T_{e q}=$ 13.18181s can be determined, substituting the equivalent mass and equivalent period into (16), equivalent stiffness $K_{e q}=5.818931 \mathrm{kN} / \mathrm{mm}$ can be determined, and finally calculate the total shear $V_{b}$ of structure base and lateral force $F_{i}$ of each floor by Eq. (17) and (18), and the results are shown in Table 4.

\subsubsection{To Design According to the Performance Level " Prevent Collapse "}

The structural performance level with rare earthquake of 7-degree, taking limit value of inter-storey drift ratio $\theta_{\text {Ta }}$ $=0.025$, figuring out lateral $\delta_{d, i}$ by formula (1), substituting into formula (6) to obtain the structure equivalent displacement $\Delta_{\mathrm{eq}}=631.0687 \mathrm{~mm}$, substituting equivalent displacement into formula (7) to obtain the equivalent mass $M_{e q}=25611.4 \mathrm{t}$. By formula (14) - (15) the equivalent period $T_{e q}=9.281622 \mathrm{~s}$ can be determined, substituting the equivalent mass and equivalent period into (16), equivalent stiffness $K_{e q}=11.73668 \mathrm{kN} / \mathrm{mm}$ can be determined, and finally calculates the total shear $V_{b}$ of structure base and lateral force $F_{i}$ of each floor by formula (17) and (18), and the results are shown in Table 5. 
With above frequent earthquake, moderate earthquake and rare earthquake, base shear and top floor displacement of frame structures can be plotted in the coordinate system shown in Fig. (8). Curve OABCD is a kind of $\mathrm{V}-\delta$ curve, which needs framework to meet the requirements of performance objectives, such as "intact and basically intact", "slight damage", " life safety" and "prevent collapse ", called the demand curve for short.

When combining the seismic effect calculated as above with the corresponding gravity load effect, the internal force design value of member section is achieved, then carrying out the member section design $[25,26]$, and taking the necessary structural details measures. Then ABAQUS program can be used to do nonlinear static analysis for composite frame structure, in order to simplify the model, analyzing the two-dimensional model of a plane frame on Yaxis direction, to obtain the plastic hinge distribution of composite frame structure and the order of the hinge appearing and base shear-top displacement curve (pushover curve), effective seismic load acting on framework adopting horizontal loading mode of parabolic distribution, because parabolic distribution horizontal loading mode can better reflect higher mode influence of structure under seismic effect. The calculation Eq. is:

$F_{i}=V_{b} \frac{w_{i} h_{f, i}^{k}}{\sum_{i=1}^{n}\left(w_{i} h_{f, i}^{k}\right)}$

In which:

$k= \begin{cases}1.0 & T \leq 0.5 \mathrm{~s} \\ 1.0+\frac{T-0.5}{2.5-0.5} & 0.5 \mathrm{~s} \leq \mathrm{T} \leq 2.5 \mathrm{~s} \\ 2.0 & T \geq 2.5 \mathrm{~s}\end{cases}$

Where, $w_{i}$ is the representative value of gravity load in the i layer; $h_{f, i}$ is the height from the ground to the i layer; $V_{b}$ is the total seismic shear of the structure base; $\mathrm{T}$ is the basic

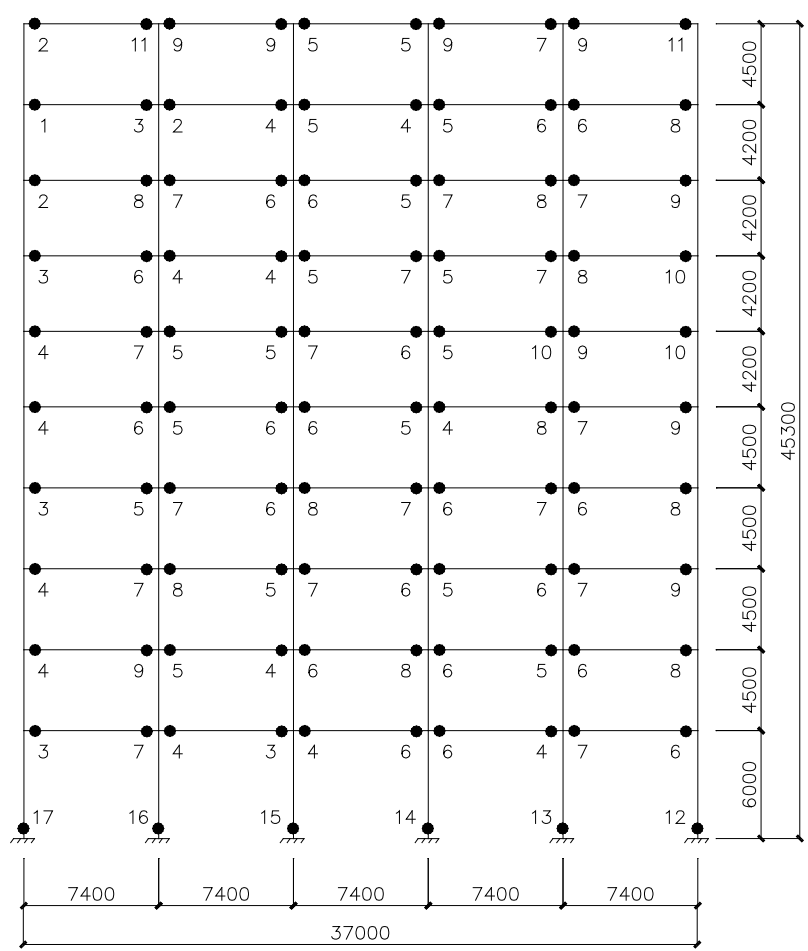

Fig. (9). The distribution and order of plastic hinge of composite frame.

period of structure. That is the same as the horizontal calculation formula of earthquake function $F_{x}$ given by American Load Code ASCE/SEI 7-10 [1], comparing with the calculation result of horizontal load distribution pattern under the distribution of del. Pushover analysis of the distribution of the base shear is shown in Table 6. Fig. (9) illuminates the distribution and the order of the plastic hinge for composite frame structure. Base shear-top displacement curve (pushover curve) and the demand curve are shown in Fig. (10). Fig. (10) shows that pushover curve of horizontal load pattern under the distribution of parabolic and triangular are all on the demand curve, which indicates the composite

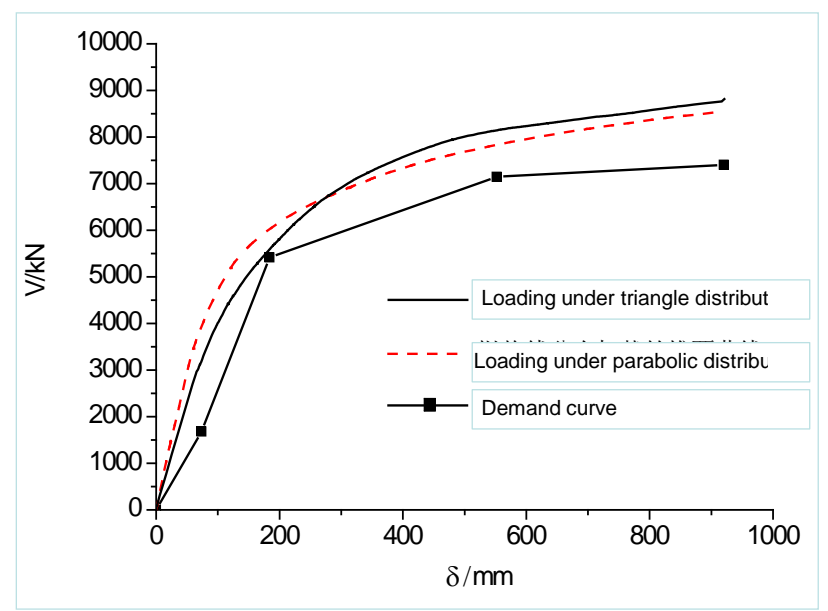

Fig. (10). The comparison of demand curve and pushover curve. 


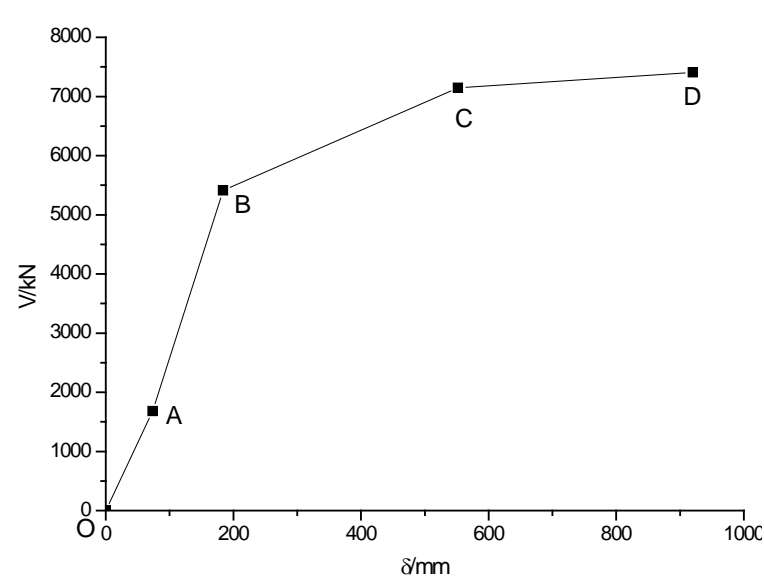

Fig. (8). demand curve.

frame (CCSHRCS) designed, meeting the requirements of performance objectives (Liang 2011) [25].

\section{CONCLUSIONS}

The present study describes the advantages and disadvantages of the current China seismic design code, since there are many advantages for the direct displacementbased design (DDBD) method, DDBD methods are proposed to use for seismic design of composite CCSHRCS frame structure. According to the characteristics of composite CCSHRCS frame structure, flowchart of DDBD can be raised, and combined with a variety of Seismic Design Code at home and abroad, structural seismic performance objectives, performance levels and the major steps of DDBD method were proposed. The feasibility requirements of site, describes the scope and basic principle of seismic concept design of structure, proposes preliminary design of the structure to determine process of performance objectives and the seismic performance evaluation, seismic performance standards and performance evaluation methods of composite CCSHRCS frame structure were suggested. Finally, taking a composite CCSHRCS frame structure with 10 floors as an engineering example, describing in detail the seismic design process of the composite CCSHRCS frame structure by using the method of DDBD. Performance verification studies show that the method can be regarded as an appropriate alternative to current force based on seismic design of structures. The method, in terms of absolute maximum storey displacement, maximum inter-storey drifts and storey ductility demands performed quite satisfactorily, even for tall models. The DDBD methodology is able to design structures with quite controlled residual behavior.

\section{CONFLICT OF INTEREST}

The authors confirm that this article content has no conflict of interest.

\section{ACKNOWLEDGEMENTS}

The authors are grateful for the financial support provided by the Natural Science Foundation of China (Project No. 51308419, 51178356 and 51108348) and
Zhejiang Provincial Natural Science Foundation of China(Project No. LQ13E080005 and Y1110567).

\section{REFERENCES}

[1] ASCE7-10, "Minimum design loads for buildings and other structures”, American Society of Civil Engineers: Reston, 2010.

[2] GB 50011-2010, "Code for Seismic Design of Building, China Architecture and Building Press", Beijing, 2010 (in Chinese).

[3] M. J. N. Priestley, "Myths and fallacies in earthquake engineering conflicts between design and reality", Bulletin of the New Zealand National Society for Earthquake Engineering, vol. 26, no.3, pp. 329-341,1993.

[4] M. J. N. Priestley, G. M. Calvi, and M. J. Kowalsky, Displacement Based Seismic Design of Structures. IUSS Press: Pavia, Italy, 2007.

[5] D. Zonta, M. Piazza, P. Zanon, C. Loss, and T. Sartori, "Direct displacement-based design of glulam timber frame buildings", In: $14^{\text {th }}$ World Conference on Earthquake Engineering, 2008, pp. 1217.

[6] S. Malekpour, H. Ghaffarzadeh, F. Dashti, "Direct displacement based design of regular steel moment resisting frames", Procedia Engineering, vol. 14, pp. 3354-3361, 2011.

[7] T. J. Sullivan, T. Maley, and G. M. Calvi, "Seismic Response of Steel Moment Resisting Frames Designed Using a Direct DBD Procedure", In: 8th International Conference on Structural Dynamics, Eurodyn, 2011, p. 730.

[8] S. Malekpour, and F. Dashti," Application of the direct displacement based design methodology for different types of RC structural systems", International Journal of Concrete Structures and Materials, vol. 17, no. 2, pp. 135-153, 2013.

[9] T. J. Sullivan, "Highlighting differences between force-based and displacement-based design solutions for RC frame structures", Structural Engineering International, vol. 23, no. 2, pp. 122-131, 2013.

[10] T. J. Sullivan, M. J. N. Priestley, and G. M. Calvi, A Model Code for the Displacement-Based Seismic Design of Structures. DBD12, IUSS Press, Pavia, Italy, 2012.

[11] T. J. Sullivan, M. J. N. Priestley, and G. M. Calvi, "Development of an innovative seismic design procedure for frame-wall structures", Journal of Earthquake Engineering, vol. 9, no. Special Issue 2, pp. 279-307, 2005.

[12] T. J. Sullivan, M. J. N. Priestley, and G. M. Calvi, "Direct displacement based design of frame-wall structures", Journal of Earthquake Engineering, vol. 10, Special Issue 1, pp. 91-124, 2006.

[13] W. Li, and Q. N. Li, "Performance-based seismic design of complicated tall building structures beyond the code specification", The Structural Design of Tall and Special Buildings, vol. 21, pp. 578-591, 2012.

[14] American Society of Civil Engineers(ASCE), "FEMA 356 Prestandard and commentary for the seismic rehabilitation of buildings, Washington, DC”, Federal Emergency Management Agency, 2000.

[15] ICC, "International Building Code, CA (USA)", International Code Council, 2003.

[16] JSCA. 2000, "Structural Design by Response Control Methods. Japan Structural Consultants Association”, Japan, Shokokusha Publishing Co. Ltd. ,2000 [in Japanese].

[17] A. King, and R. Shelton, "New Zealand advances in performancebased seismic design", In: $13^{\text {th }}$ World Conference on Earthquake Enginering, Canada, 2004.

[18] A. Heidebrecht, "Code development issues arising from the preparation of the seismic provisions of the national building Code of Canada", In: $13^{\text {th }}$ World Conference on Earthquake Enginering, Canada, 2004.

[19] SEAOC.Vision 2000., "Conceptual Framework for PerformanceBased Seismic Engineering of Buildings", Structural Engineers Association of California, Sacramento, CA, USA, 1995.

[20] FEMA. FEMA450, "NEHRP Recommended Provisions for Seismic Regulations for New Buildings and Other Structures, Part 1: Provisions", Washington (DC, USA), BSSC, 2003. 
[21] ICC, “International Building Code, CA (USA)", International Code Council, 2006

[22] P. Gulkan, and M. Sozen, "Substitute structure method for seismic design in reinforced concrete", ACI Journal, pp. 71-74, 1974.

[23] X. W. Liang, Y. J. Huang, and Q. W. Yang, "Displacementbased seismic design method of RC frames", China Civil Engineering Journal, vol. 38, no. 9, pp. 53-60, 2005 (in Chinese).

[24] T. J. Sullivan, G. M. Calvi, and M. J. N. Priestley, "Initial Stiffness versus Secant Stiffness in Displacement-Based Design", In:
Proceedings of 13th World Conference on Earthquake Engineering, Vancouver, B.C., Canada, Aug. 2004, no. 2888, pp. 1-6.

[25] X. W. Liang, The Theory and Method of Performance-Based Seismic Design. Beijing : China Science Press, 2011 (in Chinese).

[26] Q. Xue, C. W. Wu, and C. C. Chen, "The draft code for performance-based seismic design of buildings in Taiwan", Engineering Structures, vol. 30, pp. 1535-1547, 2008.

Received: March 24, 2015

(C) Li et al.; Licensee Bentham Open.

This is an open access article licensed under the terms of the Creative Commons Attribution Non-Commercial License (http://creativecommons.org/licenses/ by-nc/3.0/) which permits unrestricted, non-commercial use, distribution and reproduction in any medium, provided the work is properly cited. 